obsolete. In the arms race of the late nineteenth century, in particular, the turnover in weaponry created great distress and dislocation in the Russian economy.

Moreover, conditions in the Russian armed forces were often dehumanizing. Dmitrii Miliutin referred to discipline before the great reforms as a system of terror. Discipline was arbitrary and wholly at the discretion of the unit commander, and training consisted largely of drill. It was only after the Crimean War that military planners began to call for training permitting more open forms of combat using skirmish lines, and theorists such as M. I. Dragomirov began to talk about achieving discipline by developing morale and fostering unit and personal pride.

Through all this, however, the Russian army remained inadequately prepared to fulfill its basic mission. Despite the rapid growth of her own economy, Russia fell increasingly behind the Western powers in industrial production. Weapons and training remained out of date. Russian society was beginning to dissolve in that slide toward revolution. The Russian army placed a greater burden on the Russian empire than it could bear, and in the conflicts of the early twentieth century it proved unable to fulfill the trust placed in it by its society.

ForrestT A. MiLler

Vanderbilt University

\title{
A HISTORY OF RUSSIAN AND SOVIET SEA POWER. By Donald $W$. Mitchell. New York: Macmillan, 1974. xxix, 657 pp. $\$ 15.00$.
}

In this massive volume Donald Mitchell traces the rise, fall, and resurgence of the Russian navy. The history begins in the ninth century, with an account of efforts by Varangian pirates to attack Byzantium; it ends more than one thousand years later, with a geographic survey of the present Soviet maritime position. In between, Mitchell describes in some detail the personages, building programs, and innumerable battles which form the tradition of the Russian fleets, and presumably have helped to shape the present-day Soviet conception of the role of naval power.

This is an interesting book. Mitchell writes well, and his descriptions of the various campaigns are often quite vivid. The account of the Russo-Japanese war is extremely well done, especially the story of the incredible voyage of the Russian fleet from the Baltic Sea, around Africa, and through the Indian Ocean, only to meet disaster in the Tsushima Straits (between Korea and Japan).

As a work of serious scholarship, however, the book unfortunately falls far short of the mark. Three kinds of shortcomings combine to rule out this volume as a definitive history of the Russian navy.

1. The book is marred by simple factual inaccuracies, many of which could have been avoided by more careful editing. Thus President Nixon is said to have ordered the mining of North Korean harbors in 1972, a date in the ninth century is listed as 1862 , and so forth.

2. Virtually no references are given. Instead of documentation the reader is offered a brief bibliographic note for each chapter, which only lists the major sources consulted. The decision not to include adequate documentation could reflect the publisher's desire to produce a more readable and therefore more popular volume. On the other hand, Mitchell notes in his preface that the first draft was based solely on English-language sources and that foreign-language (including Russian) sources, which were used in preparing later drafts, were not fully satisfactory. Thus the lack of documentation may indicate serious shortcomings in 
the material underlying the volume. But in any case, without documentation, one has little basis to judge the completeness, accuracy, or quality of the history.

3. The most important failing in this writer's judgment is that the volume presents a mass of information with little analysis. True, many (this writer included) find accounts of naval battles of great interest. But what are we to make of these victories and defeats? What impact did all of this have on the broader history of the Russian state, or the future development of the Russian navy? Questions such as these are addressed only superficially, and because of it the book is of little value other than as an introductory survey.

These shortcomings are intensified and made brutally evident in the final chapters. Mitchell's description of the Soviet navy since the Second World War is very poor. His account of modern Soviet maritime capabilities is naive, exaggerated, and indiscriminate. The sharp disputes within the Soviet Union over the proper role of seapower and the optimal configuration of naval forces are barely treated, and then only in the most simplistic fashion. Factors as disparate as the quality of food on Soviet ships, Soviet antisubmarine capabilities, and the size of the Soviet Mediterranean squadron are treated almost evenhandedly. The author seems compelled to mention every element touching on Soviet naval capabilitiesfrom China's navy to Soviet fishing fleets. In brief, in pursuing the history of the Soviet navy after World War II, Mitchell attempts to cover far too much, in too limited a space, and without adequate preparation.

One hates to close on such a low note, because the book is an interesting one, fun to read, and a comprehensive introduction to the subject. As serious history, however, it must be considered a failure.

BARRY M. BLECHMAN

The Brookings Institution

THE SHORT VICTORIOUS WAR: THE RUSSO-JAPANESE CONFLICT, 1904-5. By David Walder. London: Hutchinson, 1973. New York: Harper \& Row, 1974. 321 pp. $\$ 10.00$.

As the first of the great twentieth-century wars, and as an event in the history of both belligerents, the Russo-Japanese War fully deserves the attention it has received from successive authors. However, the best description of this war remains the British Official History, Naval and Military, of the Russo-Japanese War (Committee of Imperial Defence, vols. 1-111, London, 1910-20). This work made good use of the very full reports sent in by British attaches with the Russian and Japanese forces. Its defects are its limitation to purely military and naval topics, and its too uncritical use of unreliable published accounts by Russian eyewitnesses. The diplomatic aspects have since been illuminated by academic research, but scholars have not yet been very helpful in clarifying other features of the war; this reviewer in a previous book has repeated, as fact, the story that when the Japanese attacked the Russians' Port Arthur squadron the officers of the latter were attending a party, while a distinguished British historian recently turned the battle of Tsushima upside down by mistranslating minonostsy as "minelayers" instead of "torpedo boats."

David Walder, a British journalist and member of Parliament, has written what is probably the best of the popular accounts so far. His book is readable, and he avoids several of the traps into which previous writers have fallen. How- 